\title{
How a group service failure at a restaurant turns into an individual dissatisfaction? A scenario-based experiment"
}

\author{
Ozan Güler*, A. Celil Çakıcı
}

\author{
Keywords: \\ Group Service Failure, \\ Negative Emotions, \\ Emotional Contagion, \\ Dissatisfaction, \\ Restaurants
}

\author{
Article History: \\ Submitted: 06/02/2020 \\ Accepted: 17/10/2020
}

\begin{abstract}
When it comes to service failures, restaurants are one of the most experienced one in the tourism and hospitality businesses. High level of service interaction and presence of other consumers in a groups of different size make the failures more complicate. Customers whose service expectation is not meet inform other group members through their negative emotions and may lead to a similar change in the emotions of others. Therefore, dealing with service failure requires more inclusive perspective. In this context, the main purpose of this research is to understand the relationship between service failure and dissatisfaction from the point of group service interaction. To that end, this study aims to investigate the effect of the negative emotions and emotional contagion on the perceived service failure and dissatisfaction. To collect data scenario-based experiment was applied through both online and face to face survey. Based on 1437 scenario based questionnaire structural equation modeling analysis was performed. Results show that the dominant factor effecting their service failure perception is the feeling of disappointment rather than anger in group failures. Emotional contagion is also effective on service failure perception. Neither negative emotions nor contagion has direct effect on dissatisfaction. That is, consumers' dissatisfaction feelings occur if they support their emotional reactions with their cognitive assessments of service failure.
\end{abstract}

\section{Introduction}

From the perspective of consumption, the main underlying motivation behind purchasing and consuming is to reach an inner psychological and physiological balance by meeting the needs (Koç, Aydın, Akdeniz-Ar \& Boz, 2017, p. 42). Similarly, for businesses, the main reason for selling and providing services is to reach a balance while gaining profit and maintaining their own economic assets. However, service failures in the consumption process cause negative economic and social interactions between consumers and businesses (Smith, Bolton \& Wagner, 1999: 357; Koç, 2013, p. 3684), increasing consumer tension and dissatisfaction (Koç et al., 2017, p. 42). This further leads to negative behavioral tendencies among consumers such as talking negatively about businesses, complaining as well as low revisit intention (Richins, 1982, p. 502; Oliver, 1993, p. 418; McAlister \& Erffmeyer, 2003, p. 342). As the Prospect Theory proposed by Kahneman and
Tversky suggest, individuals value losses more than gains. Therefore, the negative emotions of consumers that result from poor services are greater than their happiness that results from satisfactory services (Koç, et al., 2017, p. 44).

Service failure is defined as service mishap and/or problems that occur during a consumer's service experience with a business. (Richins, 1982, p. 502; Maxham, 2001, p. 11). Although service-oriented businesses take precautions against potential problems, it is almost impossible to avoid service failures completely due to the characteristics of the service such as intangibility, inseparability, heterogeneity and perishability (Zeithaml, Berry \& Parasuraman, 1988, p. 46; Maxham, 2001, p. 11; Koç, 2017, p. 1). When such interaction between people and services is very strong and tourism and hospitality businesses, which are mostly experienced with groups of different sizes, are in question (Wei, Miao, Cai \& Adler, 2012, p. 764; Koç and Boz, 2014, p. 144), a more inclusive perspective

\footnotetext{
"Corresponding Author

Asst. Prof. Dr., Mersin University, Tourism Faculty, Department of Gastronomy and Culinary Arts, Mersin, Turkey, Research Paper

Ozan Güler: Email: ozanguler@mersin.edu.tr, Orcid Id:0000-0002-0062-3983

A. Celil Çakıcı: Prof., Dr., Mersin University, Tourism Faculty, Departments of Tour 
than an individual perspective is required for service failure (Schanzel, 2010, pp. 555-556). Group service failure is described as a service that does not meet the expectations of all or most of the customers who experience "common consumption" and that causes complaints (Wei et al., 2012, p. 764; Du, Fan \& Feng, 2014, p. 2; Du, Jang \& Liu, 2019, pp. 217-218). If the service performance perceived by individuals is below expectations, this causes a feeling of dissatisfaction and leads to negative emotions (Chang, 2008, p. 113; Han and Back, 2008, p. 467; Mattila and Ro, 2008, p. 90; Koç et al., 2017, p. 43). As the severity of negative emotions increases, customers' satisfaction with service interaction gradually decreases (Smith and Bolton, 2002, p. 8; Chang, 2008, p. 113; Han and Back, 2008, p. 467).

The main reason why group service failure causes serious problems for businesses is the high level of interaction and emotional sharing among groups (Spoor and Kelly, 2004, p. 398). The presence of other consumers during the service consumption may have an influence on one's service evaluation due to interpersonal relationships (Huang et al., 2014, p. 182) and cause one to behave differently than when s/he are alone (Du et al., 2014, p. 2; Huang, et al., 2014, p. 182; Koç, 2016, p. 447). Customers who deem the service as inaccurate inform other group members about their negative emotions and may lead to a similar change in the emotions of other group members (Pugh, 2001, p. 1020; Du et al., 2014, p. 3). For this reason, while discussing the issue of group service failure, it is essential to consider inter-group emotional contagion in addition to the emotional reactions of consumers. Just as the perceived service quality gives insights into individuals' satisfaction and future consumption trends based on objective factors, aspects such as emotional reactions and transfer of emotions can provide information on the same variables based on sensory factors (Gracia, Bakker \& Grau, 2011, p. 459).

The concept of emotional contagion, is -the act of transferring one's mood and emotions to the individuals next to him/her (Spoor and Kelly, 2004, p. 402). It explains how behavioral tendencies of individuals alter the within the groups (Barsade, 2002, p. 647; Hennig-Thurau, Groth, Paul \& Gremler, 2006, p. 59; Du et al., 2014, p. 3). When people enter a group, they are explicitly exposed to other groups members' emotions which can be by the valence (positive or negative) of the emotion being displayed and the energy level with which the emotion is expressed (Barsade, 2002, p. 647).
Studies in the relevant literature point out that group interaction increases the severity of individuals' emotional responses (Wild, Erb \& Bartels, 2001, p. 110; Becker, Tausch \& Wagner, 2011, p. 1587). Du et al. (2019) examined the process of group emotional contagion based on service errors at restaurants and revealed that individuals with high levels of negative emotions in the group strongly affect those with low levels of negative emotions.

Restaurant businesses, which are an indispensable part of the tourism and hospitality industry, mostly serve groups (Du et al., 2014, p. 1). They are among the top businesses with the highest number of cases regarding service failures, negative emotional reactions and the contagiousness of these reactions (Mattila, 1999, p. 285). For restaurant businesses, service errors in group service indicate multiple emotional changes that are far more serious and are not easy to deal with than service errors involving individual customers (Du et al., 2014, p. 1). Understanding the emotional state of consumers in the service process, so to say, means understanding their overall evaluations and satisfaction for the service (Kuo and Wu, 2012, p. 128). From this standpoint, this present study seeks to explore the relationship between emotional responses, perceived service failure and dissatisfaction from with reference to restaurant group service errors. To that end, it examines the effect of negative emotions and the emotional contagion on the perceived service failure and service dissatisfaction.

The literature review shows that there has been limited research on emotional reactions and emotional contagion in regard to service failure in groups and examine their effect on consumer dissatisfaction (Bonifield and Cole, 2007; Mattila and Ro, 2008; Du et al., 2011; Yang and Mattila, 2012; Du et al., 2014; Huang, et al., 2014; Maher and Sobh, 2014; Du, et al., 2019). A significant number of the studies in the literature have overlooked the variable of emotional contagion and only focused on the effects of emotional reactions on variables such as service failure and satisfaction/dissatisfaction, mostly based on the perception of individual failure (Du et al., 2019, p. 218). Nevertheless, restaurants are often among the businesses where group service and service interaction the most (Huang, et al, 2014, p. 181; Du et al., 2014, p. 1). On the other hand, numerous studies on restaurants in the literature discussed a single service problem based on service failure scenarios (Ok, Back \& Shanklin, 2007; Ha and 
Jang, 2009; Söderlund and Rosengren, 2010; Du et al., 2011; Kwon and Jang, 2012; Yang and Mattila, 2012; Huang et. al., 2014; Zhou, Tsang, Huang \& Zhou, 2014; Kim, Miao \& Magnini, 2016). This study collected its data with a scenario based survey where a multi-service error affects all members of a group of six in an à la carte restaurant. Thus, this study will potentially add new insights to the literature on tourism and service marketing.

\section{Conceptual Framework and Hypotheses}

Effect of Negative Emotional Reactions on Perceived Service Failure and Service Dissatisfaction

Emotional reactions are an integral part of everyday life (Vijayalakshmi and Bhattacharyya, 2012 , p. 363) and affect behaviors and it is sometimes possible to control them and sometimes not (Odabaşı and Barış, 2015, p. 183). In simple terms, emotions can be defined as "the reflection of one's mood as a result of a state that arises from cognitive appraisals of events or one's own thoughts" (Bagozzi, Gopinath \& Nyer, 1999, pp. 184-185). Individuals' emotional responses contain feelings of positivity (happiness, joy, appreciation, satisfaction) and negativity (regret, anger, boredom, fear, etc.) rather than neutral information (Koç, 2016, p. 303). Negative emotional reactions affect individuals' thinking, judgment and other behaviors (Boshoff, 2012, p. 401), and are accompanied by physical indicators such as an increase in blood pressure, accelerated heartbeat, pale skin, shaking hands and tremor, etc. (Koç, 2016, p. 304). Emotional reactions are also a key resource to provide information about service interaction and outcomes in relation to consumer behavior (Mattila and Enz, 2002, pp. 270-271). According to previous studies, emotional reactions lead to a wide variety of consumer behaviors (Bagozzi and Dholakia, 2006, p. 50). The literature on consumer behavior shows that negative emotional reactions have been mostly discussed in the context of their effects on perceived service failure, service quality, dis/satisfaction, complaint behavior and behavioral intention. On their study on the relationship between service dissatisfaction, anger, and various complaint behaviors, Bougie, Pieters \& Zeelenberg (2003) found a moderately significant correlation between anger and service dissatisfaction $(\mathrm{r}=.510$, $\mathrm{p} \leq 0.001)$. They also reported that anger significantly affected the tendency of individuals to convey their complaints to the business $(B=.546$, $\mathrm{p} \leq 0.001$ ). Bonifield and Cole (2007), in their research based on a service failure scenario related to a delayed delivery, indicated that anger positively affected the complaint intention of the customers $(B=.418, \mathrm{p} \leq .01)$, and had a negative significant impact $(B=-.302, \mathrm{p} \leq .01)$ on positive behavioral consumption tendencies. They further revealed that the feeling of regret did not have a significant effect on both dependent variables $(B=$ $.410, \mathrm{p}=.20$ ). Mattila and Ro (2008) carried out a study based on a scenario on restaurant service and found that feeling of anger significantly affected the tendency of customers to forward their complaints to the business $(B=.135, \mathrm{p} \leq 0.01)$.

Han, Back \& Barrett (2009) also reported that customers' feelings of anger significantly and negatively affected their perceived service satisfaction $(B=-.510, p \leq 0.01)$. Similarly, Han and Jeong (2013) determined that feeling of anger among participants that results from poor restaurant services negatively and significantly affected their satisfaction $(B=-.451, \mathrm{p} \leq 0.01)$. Maher and Sobh (2014) examined the relationship between the collective anger of customers who experienced service failure in groups, employee and perceived cultural distance as well as recommendations. They concluded that the anger of the individuals who perceived high levels of service failure significantly differed from that of those who perceived low levels of service failure ( $\bar{x}$ $=3.70 / \bar{x}=3.33, \mathrm{p} \leq 0.01)$. Song and $\mathrm{Qu}(2017)$ studied with a sample of 435 ethnic restaurant customers and ascertained that the negative feelings perceived by the participants during their service experiences negatively and significantly affected their service satisfaction $(B=-.251, \mathrm{p} \leq 0.001)$. Cho, Jang \& Kim (2017) investigated a scenario involving beverage spills to explore the mediating role of severity of service failure between emotions and dissatisfaction and found out that both regret $(B=.312 \mathrm{p} \leq 0.01)$ and frustration $(B=.323 \mathrm{p} \leq 0.001)$ had a significant impact on dissatisfaction. Thus, the following hypotheses are proposed:

H1: Negative emotions (anger \& disappointment) resulted from service errors have a significant and positive impact on perceived service failure.

H2: Negative emotions (anger \& disappointment) resulted from service errors have a significant and positive impact on service dissatisfaction.

\section{Effect of Emotional Contagion on Perceived Service Failure and Service Dissatisfaction}

Individuals tend to share their thoughts, personal values, and feelings with the groups they are in (Vijayalakshmi and Bhattacharyya, 2012, p. 364). Emotional contagion is one of the concepts that explain this act, which individuals perform 
sometimes explicitly and consciously and sometimes unconsciously. Emotional contagion refers to "the process by which a person or group influences the emotions or behavior of another person or group through the conscious or unconscious induction of emotion states and behavioral attitudes" (Schoenewolf, 1990, p. 50). Emotional contagion has been considered to be a multilevel phenomenon because emotional expressions of one individual produce a corresponding experience in the other person (Vijayalakshmi and Bhattacharyya, 2012, p. 364). It can be defined in more detail as "the tendency to automatically mimic and synchronize facial expressions, vocalizations, postures and movements with those of another person's and to converge emotionally." (Hatfield, Cacioppo, Rapson, 1993, p. 96). This three step process of emotion transfer also forms the basis of the emotional contagion theory (Hatfield et al., 1993, pp. 96-99; Wild, Erb and Bartels, 2001, p. 110; Barsade, 2002, pp. 647-648). To summarize, emotional contagion theory explains a process in which people are collectively influenced by psychophysical, cognitive, behavioral and social decisionmaking processes (Cakici and Guler, 2017, p. 147).

Fig 1. Group Emotional Contagion Model

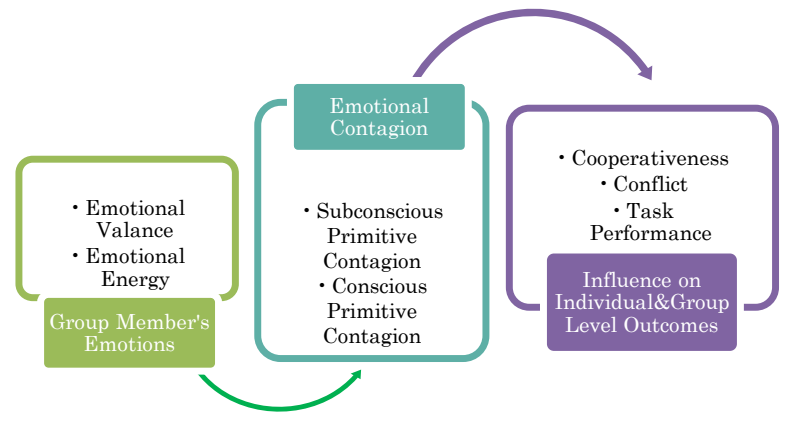

Source: Barsade, 2002.

Groups of different sizes are where emotion transfers specified in the definition of emotional contagion are experienced most commonly and intensely. Genetic codes, gender, previous experiences and personal characteristics are the main factors that affect the tendency to experience emotional contagion (Doherty, 1997, pp. 133-134; Hatfield et al., 2014, pp. 165-166). Besides, variables such as the number of individuals in the group (Du et al., 2014), degree of commitment to the group (Wei et al., 2012, p. 764; Boshoff, 2012, p. 403) and how close individuals in the group are (Du et al., 2014; Huang et al., 2014; López-López, Ruizde-Maya \& Warlop, 2014) are important variables that affect the severity and direction of emotional responses and thus the extent of the contagion.
Studies in the literature indicate that positive and negative emotional contagion is addressed based on the interactions between both employeecustomer and customer-customer and is a significant variable in terms of consumers' emotional reactions, perceived service failure, service quality, the tendency to complain, service satisfaction/dissatisfaction and behavioral tendencies. Barger and Grandey (2006) explored the impact of emotional contagion between customers and employees on service quality evaluations made by customers and their satisfaction from service interaction. Their analyses showed that employees' smile significantly and positively affected customers' smile $(B=.370, \mathrm{p} \leq 0.05)$, that employee smiling significantly and positively affected the perceived service quality of customers $(B=.140, p \leq 0.05)$ and that perceived service quality significantly and positively mediated the relationship between employee smiling and service satisfaction $(B=.510$, $\mathrm{p} \leq 0.05)$. In their research based on experimental scenarios, Söderlund and Rosengren (2010) found out that there is a significant difference between delivering service with a smiling facial expression and with a neutral facial expression in terms of customer satisfaction $(\bar{x}=8.23 / \quad \bar{x}=6.21, \quad \mathrm{p} \leq 0.01)$. Wieseke, Geigenmüller \& Kraus (2012) performed a study on empathy, one of the most important indicators of emotional contagion. Results show that empathy between employee and customer had a positive and significant mediating effect on customer satisfaction $(B=.160, \mathrm{p} \leq 0.01)$.

Du et al., (2014) studied the relationship between emotional contagion and complaint intentions in group service failure and determined that group members were affected significantly and positively by the displays of anger by surrounding customers ( $\left.B_{\text {hotel }}=.138, \mathrm{p} \leq .001 / B_{\text {restaurant }}=.607, \mathrm{p} \leq .001\right)$, that customers in group service failure had significantly higher levels of anger than individual customers $\left(\overline{\mathrm{x}}_{\text {group }}=5.80 / \quad \overline{\mathrm{x}}_{\text {individual }}=5.14, \mathrm{p} \leq 0.001\right)$ and that customers in group service failure had significantly higher complaint intention than individual customers $\quad\left(\overline{\mathrm{x}}_{\text {group }}=5.67 / \quad \overline{\mathrm{x}}_{\text {individual }}=4.31, \mathrm{p} \leq 0.001\right)$. Huang et al. (2014) explored the effect of others companion on complaint intentions when encountering service failure and indicated that customers encountering service failure had higher complaint intentions when they were with others than when alone $\left(\overline{\mathrm{x}}_{\text {others }}=5.80 / \overline{\mathrm{x}}_{\text {alone }}=4.50, \mathrm{p} \leq 0.001\right)$. López-López et al. (2014) aimed to determine the relationship between negative emotional reactions and service satisfaction depending on the sharing of emotions with a stranger or a friend. They 
concluded that perceived service quality and satisfaction significantly differed depending on tie strength $\quad\left(\overline{\mathrm{x}}_{\text {stranger }}=3.56 / \overline{\mathrm{x}}_{\text {friend }}=2.37, \mathrm{p} \leq .05\right)$ and $\mathrm{no} /$ sharing condition $\left(\overline{\mathrm{x}}_{\text {no-sharing }}=4.71 / \overline{\mathrm{x}}_{\text {sharing }}=5.51\right.$, $\mathrm{p} \leq .01$ ) of negative emotions. Thus, the following hypotheses are proposed:

$\mathbf{H}_{3}$ : Negative emotional contagion resulted from service failures has a positive and significant effect on perceived service failure.

$\mathbf{H}_{4}$ : Negative emotional contagion resulted from service failures has a positive and significant effect on perceived service dissatisfaction.

\section{Effect of Perceived Service Failure on Service Dissatisfaction}

The Expectancy-Disconfirmation Theory (EDT) is the underlying theory behind the widespread understanding of customer satisfaction (Blodgett and Granbois, 1992, p. 93; Boote, 1998, p. 141; Smith et al., 1999, p. 357; Chang, Khan and Tsai, 2012 , p. 602). Disconfirmation is an emotion that affects customer satisfaction when standards are not met (Oliver, 1981, p. 28). The EDT posits that satisfaction occurs as a result of subjective comparison of customers between the expected and perceived attribute levels regarding a product $(\mathrm{Oh}$, 1999, p. 69; McCollough, Berry \& Yadav, 2000, p. 121 ). If the performance of the product is above the expectations of the customer, positive disconfirmation occurs; if it meets their expectations, zero disconfirmation occurs, and if it is below their expectations, negative disconfirmation occurs (Oliver, 1980, pp. 460-462; Blodgett and Granbois, 1992, p. 94; McCollough et al., 2000, p. 121). The general assumption is the higher negative disconfirmation is, the higher the dissatisfaction would be; likewise, the higher the positive disconfirmation is, the higher the satisfaction would be (Fornell and Wernerfelt, 1987, p. 338; McCollough et al., 2000, p. 122).

Research in the literature have repeatedly shown the linear correlation between perceived service quality and satisfaction through the data obtained from restaurant customers (Cronin, Brady \& Hult, 2000; Yüksel and Yüksel, 2003; Pedraja-Iglesias and Jesus Yagüe Guillén, 2004; Tam, 2004; Ha and Jang, 2010; Ryu and Han, 2010; Naghizadeh, 2019). Some studies measured the variable of service quality as the perception or severity of service failure and revealed its effects on service satisfaction/dissatisfaction based on service failure scenarios and critical incident techniques (McDougall and Levesque, 1998; Mattila, 1999; Smith et al., 1999; Maxham and Netemeyer, 2002; McQuilken and Robertson, 2011; Yang and
Mattila, 2012; Cho et al., 2017). This study is intended to measure the perceived service failure of the participants based on their evaluations on failure in relation to the dimensions of service quality; reliability, responsiveness, trust and empathy. Thus, the following hypotheses are proposed:

H5: Perceived service failure has a positive and significant impact on service dissatisfaction.

\section{Methodology}

\section{Research Model}

The model of the study has field experimental design. Field experiment implies to determine cause-effect relationships through the data produced in the natural environment under the control of the researcher (Sekeran, 1992, p. 126; Karasar 2014, p. 87). Experimenatal designs allow researcher to manipulate variables and control nuisance affects (Sekeran, 1992, p. 120). Since the study data collection process has some restriction such as following non probability sampling, the model could be called as quasi-experimental just like the studies performed by Blodgett, Hill and Tax (1997), Smith et al., (1999), Mattila and Patterson (2004), Wirtz and Mattila, (2004) and Kim and Jang (2014). In this study, scenario based experiment was used to quantitatively test the research hypotheses to understand the relationships between the perceived negative emotional reactions, emotional contagion, service failure and dissatisfaction of the restaurant customers who experience service errors in groups. The approach of collecting data through scenarios allows an easier, more inclusive, representative, ethical and systematic research on the relevant subject, compared to retrospective research approaches (Smith et al., 1999, p. 362; Smith and Bolton, 2002, p. 10; Ha and Jang, 2009, p. 323).

\section{Scenario Development and Data Collection Instrument}

First, a service failure scenario including multiservice failure and group interaction was developed. To develop scenario, previous studies collected data via a restaurant service failure are reviewed. Then, group service failures experienced by 167 people in à la carte restaurants were collected by using an unstructured interview forms. Lastly focus group interview was carried out with graduate students, consumers and restaurant owners in order to finalize scenario. The scenario consists of multi-service errors encountered by all members of a group of six during dinner in an à la carte restaurant (See Appendix 1.). 
The first section of the questionnaire consists of 11 items to measure negative emotional reactions of the participants after the service failure. Items were adapted from the previous studies of Kalamas, Laroche and Makdessian (2008), Mattila and Ro (2008), Du, et al., (2011) and Du et al., (2014). All items were measured with five point Likert-type scales where $1=$ not at all and $5=$ very much. Second section of the questionnaire is composed of 6 items to measure participant's emotional contagions. The first group of three items (in-group contagion) were taken from study of Du et al. (2014) and the second group of three items (individual contagion intention) were taken from study of Du et al. (2011). All items were measured with five point Likert-type scales where $1=$ strongly disagree and $5=$ strongly agree. The third section of questionnaire consists of 5 items to understand participant's service quality perception. Items serve for the measurement of service quality dimensions of reliability, responsiveness, trust and empathy except for physical assets as there was no manipulation for this dimension in the scenario. The items were compiled from the studies of Cronin et al. (2000), Han et al. (2008) and Kwortnik and Han (2011). All items were measured with five point Likert-type scales where $1=$ very bad and $5=$ very good. During the statistical analysis, items were reverse coded and turned into perceived service failure. The fourth section involves 3 items to measure overall service satisfaction. The items gathered from the studies of Oliver, Rust and Varki (1997); Mattila (1999), McCollough et al. (2000), Sparks and Fredline (2007) and Kwortnik and Han (2011). All three items were measured with five point Likerttype scales where 1=strongly disagree and $5=$ strongly agree. During the statistical analysis, items converted into the scale of service dissatisfaction by means of reverse coding. The fifth section of the questionnaire includes 7 items to determine whether failures in the scenario were found realistic. Manipulation check items were adapted from previous scenario-based studies (Mattila, 1999; McColl-Kennedy, Daus and Sparks, 2003; Hess, Ganesan, Klein, 2003; Patterson, Cowley, Prasongsukarn, 2006; Ok et al., 2007; Zhou et al., 2014; Weber et al., 2014). The sixth and the last section of the questionnaire is composed of 8 items to solicit information on the respondent's demographic characteristics and dining experiences.

\section{Research Sample and Data Collection Process}

The research population are all á la carte restaurant customers in Turkey. As it is not possible to reach out all individuals in a population in terms of time, material resources and human resources, it is essential to perform sampling and to identify sampling method (Karasar, 2014, p. 111). The research sampling was determined based on two steps. The first step included a total of 21.417 people who are faculty members and graduate students at various faculties in state and private universities. The second step included the participants who reside in Mersin, Turkey, to the sampling. To identify the individuals in this sampling to participate in this study, convenience sampling method was used. The questionnaires were administered in two steps. An electronic questionnaire system was designed for faculty members and students and sent to the sample of 21.417 people electronically. A total of 689 usable surveys were collected by June 28th, 2016. All of the surveys collected electronically were completely filled in by the participants and no questions were left blank. Further, a total of 778 usable questionnaires were collected through faceto-face contact in Mersin between May 25th and June 29th, 2016. Consequently, 1.467 surveys were collected in total from these two survey applications.

\section{Reliability and Validity}

The data were first examined through multivariate outlier analysis and multi normal distribution analysis (Çokluk, Şekercioğlu and Büyüköztürk, 2010, pp. 42-44). According to the results of the outlier analysis, 30 surveys were removed from the data set and the number of the usable surveys decreased to 1.437. Prior to the descriptive and hypothesis-testing analyses, the reliability and validity of the data was tested. The only problem about the reliability scores was pertained to the item numbered 6 in emotional contagion scale ("the provocative expressions of my friends irritate me"). The reliability score of the scale increased after the relevant item was removed from the scale. As a result, the Cronbach's Alpha coefficients were found respectively 0,913 for negative emotional reactions; 0,790 for negative emotional contagion; 0,830 for perceived service failure and 0,823 for service dissatisfaction. Following the basic reliability analyses, various analyses on validity were performed on variables. These analyses were convergent, discriminant and structural validity analyses (Şencan, 2005, p. 742; Sekeran and Bougie, 2013, p. 226).

Exploratory Factor Analysis (EFA) and Confirmatory Factor Analysis (CFA) were carried out to test structural validity. Four different factor 
analyses were performed for each variable. For the $\mathrm{EFA}$, it was required that factor loadings and communalities were higher than 0,50 (Hair, Black, Babin and Anderson, 2010, p. 119) and threshold value for overlapping were no less than 0,100 , and the significance of the Bartlett's Test of Sphericity and Kaiser Meyer Olkin test was considered (Hair et al., 2010, p. 104). Based on the results of the EFA, the item numbered 1 "stressful" in the scale of negative emotional reactions and the item numbered 5 "I am very keen to capture the emotional changes of other people." in the scale of emotional contagion were removed from the scales as they had quite low communalities scores. There was no problematic item regarding other variables. Table 1 presents the detailed statistics of the exploratory factor analyses.

Confirmatory factor analysis (CFA) was performed to assess the overall model fit and validity of the measurement model (see Table 2.). For CFA, it was required that the standardized factor loadings for each item was 0.50 or above and that the error variance was below 0.90 and each dimension consisted of at least 3 items (Şimşek, 2007, p. 86; Çokluk et al., 2010, pp. 277-284; Hair et al., 2010, pp. 695-709). Furthermore, for all five constructs, average variance extracted (AVE) and composite reliability (CR) estimates were calculated to find

Table 1. The results of the EFA

\begin{tabular}{|c|c|c|c|c|c|c|}
\hline Factors & $\begin{array}{c}\text { Factor } \\
\text { Loadings }\end{array}$ & Communalities & Eigenvalues & $\bar{x}$ & $\begin{array}{c}\text { Explained } \\
\text { Variance \% }\end{array}$ & Alpha \\
\hline $\begin{array}{l}\text { Disappointment Emotional Responses } \\
\text { (DER) }\end{array}$ & & & 3.591 & 3.73 & 35.914 & 0.873 \\
\hline 11.Ignored & 0.829 & 0.706 & & 3.91 & & \\
\hline 4.Contemptful & 0.765 & 0.625 & & 3.44 & & \\
\hline 10.Upset & 0.724 & 0.655 & & 3.57 & & \\
\hline 3.Disapointed & 0.717 & 0.570 & & 3.78 & & \\
\hline 7.Regretful & 0.671 & 0.555 & & 4.05 & & \\
\hline 9.Distressed & 0.636 & 0.627 & & 3.68 & & \\
\hline Anger Emotional Responses (AER) & & & 3.113 & 3.16 & 31.131 & .877 \\
\hline 6.Enraged & 0.843 & 0.804 & & 3.24 & & \\
\hline 5.Hostile & 0.842 & 0.735 & & 2.59 & & \\
\hline 8.Irritated & 0.840 & 0.782 & & 3.13 & & \\
\hline 2.Angry & 0.644 & 0.646 & & 3.68 & & \\
\hline \multicolumn{7}{|c|}{$\begin{array}{l}\text { Explained Variance }=\% 67.045, \mathrm{KMO}=, 909, \text { Bartlett's Test of Sphericity }=\mathrm{p} \leq 0.01 \\
\text { Response categories: } 1=\text { not at all and } 5=\text { very much }\end{array}$} \\
\hline Emotional Contagion (EC) & & & 2.437 & 4.03 & 60.934 & 0.790 \\
\hline $\begin{array}{l}\text { 1.People around me are having a heated } \\
\text { discussion with sharp words. }\end{array}$ & 0.787 & 0.619 & & 4.14 & & \\
\hline $\begin{array}{l}\text { 2.People around me look quite serious } \\
\text { and angry. }\end{array}$ & 0.793 & 0.628 & & 3.62 & & \\
\hline $\begin{array}{l}\text { 3.People around me frequently shake } \\
\text { their heads to complain about the } \\
\text { restaurant. }\end{array}$ & 0.843 & 0.710 & & 4.08 & & \\
\hline $\begin{array}{l}\text { 4.I feel displeased when I see that } \\
\text { someone is not in the mood. }\end{array}$ & 0.693 & 0.480 & & 4.28 & & \\
\hline \multicolumn{7}{|c|}{$\begin{array}{l}\text { Explained Variance }=\% 60.934, \mathrm{KMO}=, 755, \text { Bartlett's Test of Sphericity }=\mathrm{p} \leq 0.01 \\
\text { Response categories: } 1=\text { strongly disagree and } 5=\text { strongly agree }\end{array}$} \\
\hline Service Failure Perception (SFP)* & & & 2.983 & 4.15 & 59.658 & $\overline{0.830}$ \\
\hline 1.Service speed failure & 0.710 & 0.505 & & 4.42 & & \\
\hline 2.Service individuation failure & 0.826 & 0.683 & & 4.20 & & \\
\hline 3.Staff appearance and manner failure & 0.772 & 0.596 & & 3.89 & & \\
\hline 4.Service professionalism failure & 0.777 & 0.604 & & 4.30 & & \\
\hline 5.Service reliability failure & 0.771 & 0.595 & & 3.92 & & \\
\hline \multicolumn{7}{|c|}{$\begin{array}{l}\text { Explained Variance }=\% 59.655, \mathrm{KMO}=, 844, \text { Bartlett's Test of Sphericity }=\mathrm{p} \leq 0.01 \\
\text { Response categories: } 1=\text { very good and } 5=\text { very bad }\end{array}$} \\
\hline Dissatisfaction (DIS)** & & & 2.217 & 4.16 & $\% 73.91$ & 0.823 \\
\hline 1.Dissatisfaction of service quality & 0.844 & 0.712 & & 4.05 & & \\
\hline 2 Dissatisfaction of dining experience & 0.869 & 0.756 & & 4.34 & & \\
\hline 3.Dissatisfaction of meeting expectations & 0.866 & 0.750 & & 4.11 & & \\
\hline \multicolumn{7}{|c|}{$\begin{array}{l}\text { Explained Variance }=\% 63.363, \mathrm{KMO}=0,718, \text { Bartlett's Test of Sphericity }=\mathrm{p} \leq 0.01 \\
\text { * Items are reverse coded and turned into failure statements. } \\
* * \text { Items are reverse coded and turned into dissatisfaction statements. } \\
\text { Response categories } 1=\text { strongly disagree and } 5=\text { strongly agree }\end{array}$} \\
\hline
\end{tabular}

Source: Authors 
Table 2. The results of the measurement model

\begin{tabular}{|c|c|c|c|c|c|c|}
\hline Factor items & $\begin{array}{c}\text { Std. } \\
\text { Loadings }\end{array}$ & $\begin{array}{c}\text { Error } \\
\text { Variances }\end{array}$ & $\mathbf{R}^{2}$ & t- values & AVE & $\mathbf{C R}$ \\
\hline Anger Emotional Responses (AER) & & & & & $\mathbf{0 , 6 5}$ & $\mathbf{0 , 8 8}$ \\
\hline 2.Angry & 0.75 & 0.44 & 0.56 & 32.29 & & \\
\hline 5.Hostile & 0.75 & 0.43 & 0.57 & 32.40 & & \\
\hline 6.Enraged & 0.88 & 0.23 & 0.77 & 40.45 & & \\
\hline 8.Irritated & 0.83 & 0.31 & 0.69 & 37.32 & & \\
\hline Disappointment Emotional Responses (DER) & & & & & 0.58 & 0.84 \\
\hline 7.Regretful & 0.70 & 0.52 & 0.48 & 28.65 & & \\
\hline 9.Distressed & 0.81 & 0.35 & 0.65 & 35.30 & & \\
\hline 10.Upset & 0.82 & 0.33 & 0.67 & 35.93 & & \\
\hline 11.Ignored & 0.69 & 0.52 & 0.48 & 28.38 & & \\
\hline Emotional Contagion (EC) & & & & & 0.54 & $\mathbf{0 . 8 0}$ \\
\hline $\begin{array}{l}\text { 1.People around me are having a heated discussion with } \\
\text { sharp words. }\end{array}$ & 0.69 & 0.53 & 0.47 & 26.28 & & \\
\hline 2.People around me look quite serious and angry. & 0.80 & 0.37 & 0.53 & 31.10 & & \\
\hline $\begin{array}{l}\text { 3.People around me frequently shake their heads to complain } \\
\text { about the restaurant. }\end{array}$ & 0.72 & 0.48 & 0.52 & 27.92 & & \\
\hline Service Failure Perception (SFP) & & & & & 0.50 & $\mathbf{0 . 8 3}$ \\
\hline 1.Service speed & 0.63 & 0.60 & 0.40 & 25.24 & & \\
\hline 2.Service individuation & 0.77 & 0.40 & 0.60 & 33.00 & & \\
\hline 3.Staff appearance and manner & 0.69 & 0.52 & 0.48 & 28.39 & & \\
\hline 4.Service professionalism & 0.71 & 0.50 & 0.50 & 29.27 & & \\
\hline 5.Service reliability & 0.72 & 0.49 & 0.51 & 29.61 & & \\
\hline Dissatisfaction (DIS) & & & & & 0.61 & 0.83 \\
\hline 1.Dissatisfaction of service quality & 0.78 & 0.40 & 0.60 & 32.81 & & \\
\hline 2 Dissatisfaction of dining experience & 0.80 & 0.35 & 0.65 & 34.35 & & \\
\hline 3.Dissatisfaction of meeting expectations & 0.76 & 0.43 & 0.57 & 31.60 & & \\
\hline \multicolumn{7}{|c|}{$\begin{array}{l}\text { Measurement Model Fit: } \mathrm{X}^{2} / \mathrm{df}=737,99 / 142=5,19, \mathrm{RMSEA}=0.056, \mathrm{SRMR}=0.044, \mathrm{RMR}=0.036, \mathrm{GFI}=0.95, \mathrm{AGFI}=0.93, \mathrm{CFI}=0.98 \\
\mathrm{NFI}=0.98, \text { Model CAIC vs Saturated CAIC }=1180.02 / 1571.36 \\
\text { Note: All factor loadings are significant at } \mathrm{p}<0.01 .\end{array}$} \\
\hline
\end{tabular}

out whether they exceeded the minimum threshold values or not (Hair et al., 2010: 709). The scales used in this study are reliable for measuring each construct. All standardized factor loadings of items were significant $(p \leq 0,05)$, greater than the minimum threshold value of 0.50 and error variances were lower than the threshold value of 0.90 (Şimşek, 2007, p. 86; Çokluk et al., 2010, pp. 277-284; Hair et al., 2010, pp. 695-709).
In addition to composite reliability (CR) and average variance extracted (AVE) estimates exceeded the minimum value of 0.50 and 0.70 subsequently (Hair et al., 2010, pp. 709-710). These estimates indicated a satisfactory convergent validity for the study. The AVE value of each construct was greater than the squared correlation between any pair of constructs, which supports discriminant validity as well (Sekeran and Bougie, 2013, pp. 227-228; Hair et al., 2010, p. 710).

Table 3. AVE and squared correlations of paired constructs - Discriminant Validity

\begin{tabular}{|l|l|l|l|l|l|l|l|l|}
\hline & $\bar{x}$ & $\begin{array}{l}\text { Std. } \\
\text { Dev. }\end{array}$ & SFP & DIS & AER & DER & EC & AVE \\
\hline SFP & 4.15 & .7206 & 1 & & & & & $\mathbf{0 . 5 0}$ \\
\hline DIS & 4.16 & .6450 & 0.4596 & 1 & & & & $\mathbf{0 . 6 1}$ \\
\hline AER & 3.16 & .9481 & 0.2016 & 0.1310 & 1 & & & $\mathbf{0 . 6 5}$ \\
\hline DER & 3.80 & .8604 & 0.2704 & 0.1927 & 0.4225 & 1 & & $\mathbf{0 . 5 8}$ \\
\hline EC & 3.94 & .7328 & 0.1062 & 0.0691 & 0.1169 & 0.1528 & 1 & $\mathbf{0 . 5 4}$ \\
\hline
\end{tabular}

SFP: Service Failure Perception, DIS: Dissatisfaction, AER: Anger Emotional Response, DER: Disappointment Emotional Response, EC: Emotional Contagion.

All squared correlations are significant at $\mathrm{p}<0.01$ 
To evaluate goodness of fit of the model firstly the normalized Chi-Square statistics and RMSEA goodness of fit statistics were analyzed (Hair et al., 2010, p. 666; Şimşek, 2007, pp. 47-48). In addition to these estimation statistics, the congruence validity of the measurement model was examined in terms of other goodness of fit indices that consider or do not consider sample size, degrees of freedom in the model and complexity of the model, such as AGFI, GFI, RMR, SRMR, CFI, NFI, NNFI, IFI, RFI, CAIC (Şimşek, 2007, pp. 47-49). The results of the first confirmatory factor analysis revealed some problems regarding the problem due to high normalized Chi-Square statistics (above 7). The item numbered 3 (disappointed) and 4 (contemptful) in the scale of negative emotional reactions and the item numbered 4 (I feel displeased when I see that someone is not in the mood.) in the scale of emotional contagion were found similar to other items and thus modifications were suggested. Then, the relevant items were removed from the model and the analysis was conducted again. Consequently, the Chi-Square statistics decreased to 5.19 and the RMSEA statistics decreased to 0,056 ; yet, there was no significant modification suggestion in the model output. As a result, all estimates of model fit indices fell within an acceptable range except for slight exceeding for the normalized Chi-Square statistics (See Table 2). However, it is known that the Chi-Square goodness of fit is highly sensitive to sample size (Şimşek, 2007, p. 14; Yılmaz and Çelik, 2009, p. 39), and the Chi-square increases particularly when sample size is more than 750 (Hair et al., 2010, pp. 666-668). Hence, the overall model fit for the measurement model was acceptable.

\section{Findings}

\section{The respondents' demographic profiles}

Table 4 represent the distribution of the demographic characteristics of the participants. As seen, the distribution of gender and marital status of the participants was almost proportionally same. In terms of age, two groups were proportionally predominant; the group aged between $22-35$, (55\%) and the group aged between $36-50 \quad(30.9 \%)$. Regarding the educational level and occupation of the participants, the number of the participants who have high educational level and work as public employees are high due to the selected sample. Most of the participants visit restaurants as a small group $(90 \%)$ six and more times in a month $(39,4)$. The last but not the least, consumers' overall service quality perception towards restaurant is average $(59,0 \%)$.

\subsection{Manipulation checks}

Manipulation and realism issues of the scenarios are the key points for the reliability and validity of the research. The realism of the scenarios is also critical for face validity, content validity, and nomological validity (Ok et al., 2007, p. 679). Based on the answers given by the participants, it is clear that they find the service failure scenario realistic $(\bar{x}=4.16 \pm, 713)$, they are very likely to experience similar thing in their daily life ( $\bar{x}=4.17 \pm, 769)$, they identify themselves with the people and event in the scenario $(\bar{x}=4.08 \pm, 796)$ and they believe that a series of errors occur in the scenario affect all

Table 4. Demographic Profiles $(n=1437)$

\begin{tabular}{|c|c|c|c|c|c|}
\hline \multicolumn{3}{|c|}{ Variables } & \multicolumn{3}{|c|}{ Variables } \\
\hline Gender & Frequency & Percentage $(\%)$ & Occupation & Frequency & Percentage (\%) \\
\hline Male & 713 & 49.8 & Public official & 987 & 69.0 \\
\hline Female & 720 & 50.2 & Employee & 200 & 14.0 \\
\hline Marital Status & Frequency & Percentage $(\%)$ & Craftsman & 55 & 3.8 \\
\hline Married & 714 & 49.8 & Retired & 22 & 1.5 \\
\hline Single & 719 & 50.2 & Housewife & 16 & 1.1 \\
\hline Ages & Frequency & Percentage $(\%)$ & Frequency of visit & Frequency & Percentage (\%) \\
\hline $18-21$ & 90 & 6.3 & At least $1-2$ in a month & 409 & 28.6 \\
\hline $22-35$ & 787 & 55.0 & 3-5 times in a month & 458 & 32.0 \\
\hline $36-50$ & 442 & 30.9 & 6 and more times in a month & 563 & 39.4 \\
\hline $51+$ & 113 & 7.9 & Group size & Frequency & Percentage $(\%)$ \\
\hline Education & Frequency & Percentage (\%) & 2-6 people & 1288 & 90.0 \\
\hline Primary education & 18 & 1.3 & 7-11 people & 132 & 9.2 \\
\hline High school & 110 & 7.7 & 12 and above & 11 & 0,8 \\
\hline College & 84 & 5.9 & Rest. Quality Perception & Frequency & Percentage (\%) \\
\hline University & 378 & 26.4 & Low & 236 & 19.9 \\
\hline Postgraduate & 842 & 58.8 & Average & 699 & 59.0 \\
\hline & & & High & 248 & 21.1 \\
\hline
\end{tabular}

Source: Authors 
individuals in the group $(\bar{x}=3.99 \pm, 796)$. Moreover, the participants found the importance $(\bar{x}$ $=3.64 \pm, 868)$, severity $(\bar{x}=3.43 \pm, 1,01)$ and size $(\bar{x}$ $=3.13 \pm, 970)$ of the service failure moderate.

\section{Hypotheses Testing}

This study drew on structural equation modeling to test the hypotheses. The structural equation model is a statistical methodology that combines confirmatory factor analyses with path models, and allows one to make inferences about latent variables based on the information obtained from covariance between observed variables (Yılmaz and Çelik, 2009, p. 11). As the variable of negative emotional reactions was explained by the subdimensions of anger and frustration based on the results of the EFA and CFA, the hypotheses $\mathrm{H} 1$ and $\mathrm{H} 2$ were tested as sub-hypotheses. In order to test the hypotheses, a structural equation model path analysis was carried out through LISREL. The hypotheses tested with path analysis were discussed in terms of statistical significance, direction and degree of impact of the correlations between variables (Şimşek, 2007, p. 12; Yılmaz and Çelik, 2009, p. 20). Figure 2 presents the symbolic representation of the findings obtained from the path analysis. First, it was examined whether all the correlations between the variables were statistically significant in terms of t-statistics values. It was found out that the impact of the variables of AER, DER and EC on SFP and the impact of SFP on DIS were statistically significant whereas the impact of the variables of AER, DER and EC on DIS were not statistically significant $(\mathrm{p}>0,05)$. Also, negative emotional reactions that include the dimensions of anger $(0,11, p \leq 0,05)$ and disappointment $(0,45, \mathrm{p} \leq 0,01)$ as well as emotional contagion $(0,14, \quad \mathrm{p} \leq 0,01)$ have positive and statistically significant impact on SFP.

Feeling of disappointment had the greatest impact on perceived service failure $(0,45, \mathrm{p} \leq 0,01)$. The perception of service failure of the participants would increase by 0,45 for each unit increase in their feeling of disappointment. Besides, the effect of perceived emotional contagion within the group on perceived service failure was higher than the feeling of anger. These three variables can explain $39 \%$ of service failure perceived by the participants. These findings also support the hypotheses $\mathrm{H} 1 \mathrm{a}, \mathrm{H} 1 \mathrm{~b}$ and $\mathrm{H} 3$. The path analysis yielded that AER, DER and EC did not have a statistically significant impact on the service dissatisfaction (DIS) of the participants $(p>0,05)$. Therefore, the hypotheses $\mathrm{H} 2 \mathrm{a}, \mathrm{H} 2 \mathrm{~b}$ and $\mathrm{H} 4$ were not supported. The last relation tested in the model was between SFP and DIS. The analysis showed that perceived service failure had a positive and statistically significant impact on service dissatisfaction $(0,80, \quad \mathrm{p} \leq 0.01)$. The service dissatisfaction of the participants would decrease by 0,80 for each unit increase in their perception of service failure. The perception of service failure of the participants explained $67 \%$ of their service dissatisfaction. These results support the hypothesis H5. According to the first four hypotheses tested, AER, DER and EC did not have a direct impact on service dissatisfaction and this impact occurred through SFP. Figure 2 presents the symbolic representation of the findings on the structural equation path analysis.

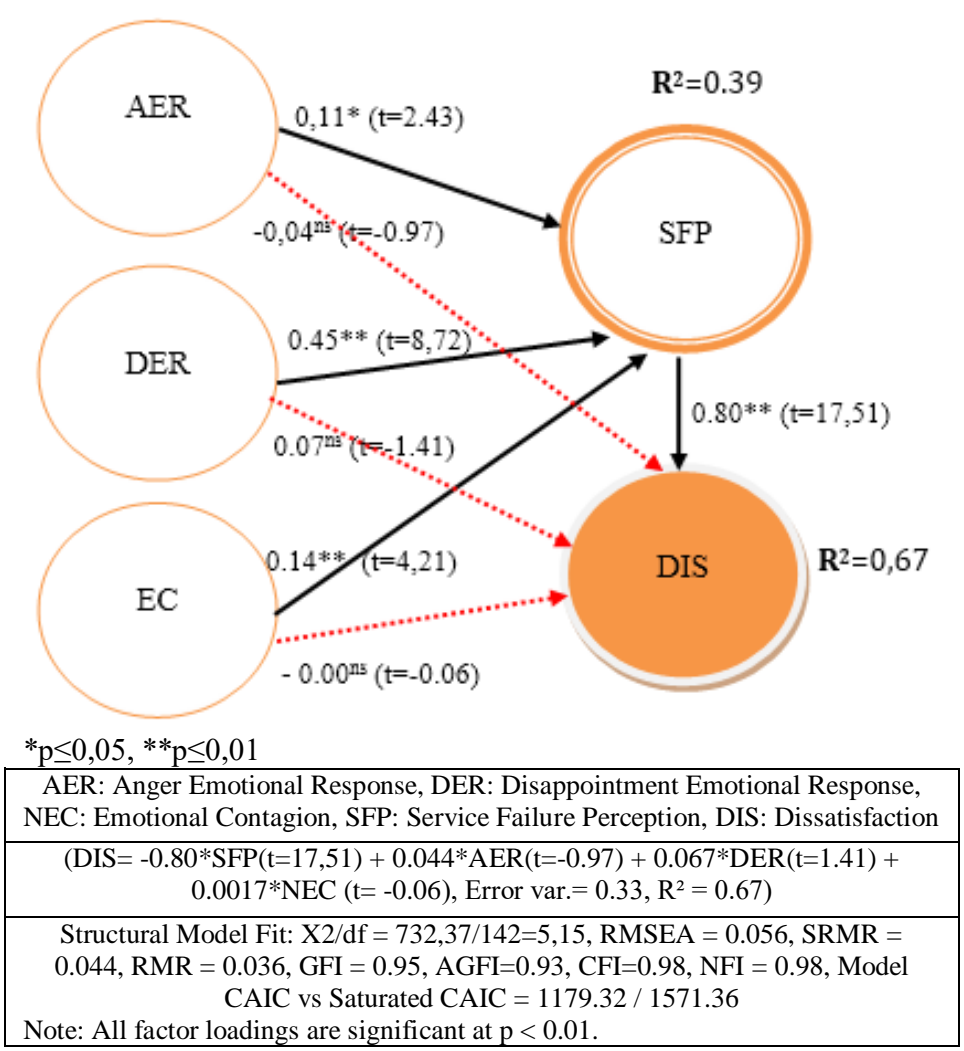

Fig. 2. The results of structural model and hypothesis testing Source: Authors

\section{Discussion and Implications}

\section{Theoretical Implications}

The findings of this study, which examines the impact of the negative emotional reactions and emotional contagion on perceived service failure and service satisfaction based on the group service experience in a restaurant, are congruent with the findings of some studies in the literature to a certain extent; on the other hand, this study also 
reveals several unique findings, which offer distinctive insights. First of all, a scenario, which was proven to provide reliable and valid results through the assessment of literature review, participant interviews, focus group interviews and expert opinion, was produced. This scenario differs significantly from previous research in the literature in that all group members experienced the service failure ( $\mathrm{Du}$ et al., 2011; Yang and Mattila, 2012; Huang et al., 2014) and also in terms of the variety of service errors experienced (Yang and Mattila, 2012; Huang et al., 2014)

This study ascertained that the feelings of disappointment and anger had a positive and significant impact on perceived service failure $(p \leq 0,05)$. These findings are mostly congruent with the literature regarding the effect of negative emotional reactions on perceived service failure (Bougie et al., 2003; Jones, Reynolds, Mothersbaugh \& Beatty, 2007; Mattila and Ro, 2008; Han et al., 2009; Kuo and Wu, 2012; Han and Jeong, 2013; Maher and Sobh, 2014; Nikbin et al., 2015; Cho et al., 2017; Song and Qu, 2017) and only differ from the study conducted by Bonifield and Cole (2007) who drew on a service failure scenario related to a delayed delivery. The authors claimed that the dimension of "anger" had a significant impact on complaint intention, which is an indicator of perceived service failure, but the feeling of regret (disappointment) did not have any significant impact. It is notable that just like negative emotional reactions, the variable of emotional contagion had a positive and significant effect on perceived service failure. These findings are congruent with the findings of Du et al. (2014), Chuang and Lin (2014) and López-López et al. (2014). It is new for the literature that the effect of the variable of negative emotional contagion on perceived service failure was higher than the feeling of anger. This is a consistent finding with the nature of being a group. When the group members in crowded groups encounter any service failure, they may avoid showing sudden and harsh reactions not to disturb the group; however, they may communicate the intense negative emotions they experienced such as neglect and regret to other group members. The findings of this study showed that perceived service failure, which consists of the dimensions of service quality, had a positive and significant impact on service satisfaction $(0,80, p \leq 0.01)$. This finding supports the findings of Smith et al. (1999), Mattila (1999), McQuilken and Robertson (2011) and Yang and Mattila (2012), who explored the correlation between individual service failure perception and individual dissatisfaction feeling in a restaurant sampling. We herein report a distinctive finding; that neither negative emotional reactions nor emotional contagion had a direct significant impact on the service dissatisfaction in spite of the previous research findings (Bougie, Pieters \& Zeelenberg, 2003; Han, Back \& Barrett, 2009; Han and Jeong, 2013; Song and Qu, 2017). The findings reveal that consumers' dissatisfaction is not affected by their emotional situations but cognitive assessments of service failure. This is most probably due to nature of being group. That is, consumers' dissatisfaction feelings occur in case of supporting their emotional reactions with service failure.

\section{Practical Implications}

Restaurant businesses, where consumption in groups is common, are among the top businesses with the highest number of cases regarding service failures (Mattila, 1999, p. 285) and service failures are inevitable even in the best restaurants, no matter how hard business managers and employees try. Restaurant employees should know that service errors may lead to feelings of regret, neglect and uneasiness among group members when they visit the restaurant, and such feelings may spread within the group. Employees are required to understand the negative mood and emotions of customers by looking at their gestures, tone of voice, mimics and hand-arm movements and to prevent these emotions from spreading within the group (Çakici and Guler, 2017, p. 154). Therefore, businesses should empower, educate and encourage their employees, who are in direct contact with customers, by authorizing them and conferring them responsibilities and initiatives to meet and value customers' expectations (Hart et al., 1990, p. 154; Shamdasani and Balakrishnan, 2000, p. 401; Maxham and Netemeyer, 2003, p. 46). Training opportunities should be developed for employees such as emotional intelligence techniques, complaint management and communication techniques and empathy, etc. (Cakici and Guler, 2017, p. 154). Business owners and managers also need to design the service atmosphere and products in a way that they support more positive emotions and moods among customers. Although service failure is inevitable in restaurants, negative emotions may be experienced less intensely or their onset may be postponed. For example, the physical atmosphere of a restaurant, a pleasant music, and a menu that consists of delicious food and drinks full of serotonin can create more positive emotions in individuals and prevent negative emotions from 
spreading within the group (Koç and Boz, 2014, pp. 142-145)

\section{Limitations and suggestions for future research} This study is not without its limitations. The findings of this study are limited by the variables, the method, the sample and the statistical analysis methods used in the study. The first limitation of this study is the use of non-probability sampling methods as the sampling method for the data collection process. The impossibility of compiling a list of people aged 18 and over who eat at à la carte restaurants at least once a month has entailed the use of non-probability sampling methods. The second limitation is that the service failure and service compensation scenarios experienced by the participants are limited to the atmosphere of an à la carte restaurant. Another limitation is that the group service experiences of the participants were explored merely based on hypothetical scenarios. The service failures used in these scenarios were not divided into major or minor failures. All participants were asked to read the same scenario. The service failure scenario mentioned about a) errors in the service delivery process, b) failures to respond to the needs and requests of consumers, and c) unexpected employee behaviors, but no errors on the taste of the food or cooking were included.

Considering these limitations, this study offers the following suggestions for researchers interested in exploring service failures. Future research may address different service errors (undercooking, hygiene, slow service, reservation error, service being rude, etc.) in different scenarios and ask the participants to read two different scenarios involving major and minor service errors to explore the emotional reactions and service evaluations of the group members. Secondly, the service failure scenario used in this study involves a service experience that six close friends participated in. Further studies may focus on different relationships between the participants (relatives, close friends, coworkers, family, etc.), group size (small, medium, large) and occasion reasons (business lunch, casual meeting, special events, etc.) to investigate the emotional reactions and service assessments of the group members. Thirdly, the measurement of the perception of the service failure of the participants was based on the hypothetically developed scenarios in the survey form that the participants were asked to read. Future research may draw on video recording as an alternative to the survey form, as in the studies performed by Barsade (2002), Du et al. (2014) and
Du et al. (2019). Fourthly, scholars may investigate the interaction between employees and customers in relation to emotional contagion. The personal interaction of customers with employees is a critical factor for their service experiences. The mental, physical or emotional involvement of customers in the service they receive is closely related to both their evaluation of the service and the way they perceive and react to service failures (Koc et al., 2017, p. 393).

\section{References}

Bagozzi, R. P., \& Dholakia, U. M. (2006). Antecedents and purchase consequences of customer participation in small group brand communities. International Journal of Research in Marketing, 23(1), 45-61.

Bagozzi, R. P., Gopinath, M., \& Nyer, P. U. (1999). The role of emotions in marketing. Journal of The Academy of Marketing Science, 27(2), 184-206.

Barger, P. B., \& Grandey, A. A. (2006). Service with a smile and encounter satisfaction: Emotional contagion and appraisal mechanisms. Academy of Management Journal, 49(6), 1229-1238.

Barsade, S. G. (2002). The ripple effect: Emotional contagion and its' influence on group behavior. Administrative Science Quarterly, 47(4), 644-675.

Becker, J. C., Tausch, N., \& Wagner, U. (2011). Emotional consequences of collective action participation differentiating self-directed and outgroup-directed emotions. Personality and Social Psychology Bulletin, 37(12), 1587-1598.

Blodgett, G. J., \& Granbois, D. H. (1992). Toward an integrated conceptual model of consumer complaining behavior. Journal of Consumer Satisfaction, Dissatisfaction and Complaining Behavior, 5(1), 93-103.

Blodgett, J. G., Hill, D. J., \& Tax, S. S. (1997). The effects of distributive, procedural, and interactional justice on post complaint behavior. Journal of Retailing, 73(2), 185-210.

Bonifield, C., \& Cole, C. (2007). Affective responses to service failure: Anger, regret, and retaliatory versus conciliatory responses. Marketing Letters, 18(1-2), 85-99.

Boote, J. (1998). Towards a comprehensive taxonomy and model of consumer complaining behavior. Journal of Consumer Satisfaction, Dissatisfaction and Complaining Behavior, 11, 140-151.

Boshoff, C. (2012). A neurophysiological assessment of consumers' emotional responses to service recovery behaviors: The impact of ethnic group and gender similarity. Journal of Service Research, 15(4), 401-413. 
Bougie, R., Pieters, R., \& Zeelenberg, M. (2003). Angry customers don't come back, they get back: The experience and behavioral implications of anger and dissatisfaction in services. Journal of the Academy of Marketing Science, 31(4), 377-393.

Çakici, A. C., \& Guler, O. (2017). Emotional Contagion and the Influence of Groups on Service Failure and Recovery. Erdoğan Koç (Eds.), In the Service failures and recovery in tourism and hospitality: A practical manual (pp: 135-159). Oxfordshire, UK: CABI.

Çokluk, Ö., Şekercioğlu, G., ve Büyüköztürk, Ş. (2010) Sosyal bilimler için çok değişkenli istatistik. SPSS ve LISREL Uygulamaları. Ankara: Pegem Yayıncilık.

Chang, J. C. (2008). Tourists' satisfaction judgments: An investigation of emotion, equity, and attribution. Journal of Hospitality \& Tourism Research, 32(1), 108-134.

Chang, J., Khan, M. A., \& Tsai, C. T. S. (2012). Dining occasions, service failures and customer complaint behaviors: an empirical assessment. International Journal of Tourism Research, 14(6), 601-615.

Cho, S. B., Jang, Y. J., \& Kim, W. G. (2017). The moderating role of severity of service failure in the relationship among regret/disappointment, dissatisfaction, and behavioral intention. Journal of Quality Assurance in Hospitality \& Tourism, 18(1), 69-85.

Cronin, J. J., Brady, M. K., \& Hult, G. T. M. (2000). Assessing the effects of quality, value, and customer satisfaction on consumer behavioral intentions in service environments. Journal of Retailing, 76(2), 193-218.

Doherty, R. W. (1997). The emotional contagion scale: A measure of individual differences. Journal of Nonverbal Behavior, 21(2), 131-154.

Du, J., Fan, X., \& Feng, T. (2011). Multiple emotional contagions in service encounters. Journal of the Academy of Marketing Science, 39(3), 449-466.

Du, J., Fan, X., \& Feng, T. (2014). Group emotional contagion and complaint intentions in group service failure: the role of group size and group familiarity. Journal of Service Research, 17(3), 326-338.

Du, J., Yang, M., \& Liu, J. (2019). Flow effect and resonance effect: group emotional contagion in service failure encounters. Journal of Contemporary Marketing Science, 2(3), 217-232.

Fornell, C., \& Wernerfelt, B. (1987). Defensive marketing strategy by customer complaint management: a theoretical analysis. Journal of Marketing Research, 24(4), 337-346.
Gracia, E., Bakker, A. B., \& Grau, R. M. (2011). Positive emotions: The connection between customer quality evaluations and loyalty. Cornell Hospitality Quarterly, 52(4), 458-465.

Ha, J., \& Jang, S. S. (2009). Perceived justice in service recovery and behavioral intentions: The role of relationship quality. International Journal of Hospitality Management, 28(3), 319-327.

Ha, J., \& Jang, S. S. (2010). Effects of service quality and food quality: The moderating role of atmospherics in an ethnic restaurant segment. International journal of Hospitality Management, 29(3), 520529 .

Hair, J. F. Jr., Black, W. C., Babin, B. J., \& Anderson, R. E. (2010). Multivariate data analysis. (7th ed.), Upper Saddle River, NJ: Prentice Hall.

Han, H., \& Back, K. J. (2008). Relationships among image congruence, consumption emotions, and customer loyalty in the lodging industry. Journal of Hospitality \& Tourism Research, 32(4), 467490.

Han, H., \& Jeong, C. (2013). Multi-dimensions of patrons' emotional experiences in upscale restaurants and their role in loyalty formation: Emotion scale improvement. International Journal of Hospitality Management, 32, 59-70.

Han, H., Back, K. J., \& Barrett, B. (2009). Influencing factors on restaurant customers' revisit intention: The roles of emotions and switching barriers. International Journal of Hospitality Management, 28(4), 563-572.

Han, X., Kwortnik, R. J. Jr., \& Wang, C. (2008). Service loyalty: An integrative model and examination across service contexts. Journal of Service Research. 11(1), 22-42.

Hart, C. W., Heskett, J. L., \& Sasser, W. E. Jr. (1990). The profitable art of service recovery. Harvard Business Review, 68(4), 148-156.

Hatfield, E., Bensman, L., Thornton, P. D., \& Rapson, R. L. (2014). New perspectives on emotional contagion: a review of classic and recent research on facial mimicry and contagion. Interpersona, 8(2), 159 .

Hatfield, E., Cacicoppo, T. J., \& Rapson, L.R. (1993). Emotional Contagion. Current Directions in Psychological Sciences, 2(3), 93-99.

Hennig-Thurau, T., Groth, M., Paul, M., \& Gremler, D. D. (2006). Are all smiles created equal? how emotional contagion and emotional labor affect service relationships. Journal of Marketing, 70(3), 58-73.

Hess, R. L., Ganesan, S., \& Klein, N. M. (2003). Service failure and recovery: The impact of relationship factors on customer satisfaction. Journal of the Academy of Marketing Science, 31(2), 127-145. 
Huang, M. C. J., Wu, H. C., Chuang, S. C., \& Lin, W. H. (2014). Who gets to decide your complaint intentions? The influence of other companions on reaction to service failures. International Journal of Hospitality Management, 37, 180-189.

Jones, M. A., Reynolds, K. E., Mothersbaugh, D. L., \& Beatty, S. E. (2007). The positive and negative effects of switching costs on relational outcomes. Journal of Service Research, 9(4), 335-355.

Kalamas, M., Laroche, M., \& Makdessian, L. (2008). Reaching the boiling point: Consumers' negative affective reactions to firm-attributed service failures. Journal of Business Research, 61(8), 813824.

Karasar, N. (2014). Bilimsel araştırma yöntemi. Ankara: Nobel Yayın Dağıtım.

Kim, J. H., \& Jang, S. S. (2014). A scenario-based experiment and a field study: A comparative examination for service failure and recovery. International Journal of Hospitality Management, 41, 125-132.

Kim, S. T., Miao, L., \& Magnini, V. P. (2016). Consumers Emotional Responses and Emotion Regulation Strategies During Multistage Waiting in Restaurants. Journal of Hospitality \& Tourism Research, 40(3), 291-318.

Koc, E. (2013). Power distance and its implications for upward communication and empowerment: Crisis management and recovery in hospitality services. The International Journal of Human Resource Management, 24(19), 3681-3696.

Koç, E. (2016). Tüketici davranışı ve pazarlama stratejileri: Global ve yerel yaklaşım. Ankara: Seçkin Yayıncılık.

Koc, E. (2017). Service Failures and Recovery. Erdoğan Koç (Eds.), In the Service failures and recovery in tourism and hospitality: A practical manual (pp: 1-8). Oxfordshire, UK: CABI.

Koc, E., \& Boz, H. (2014). Psychoneurobiochemistry of tourism marketing. Tourism Management, 44, $140-148$

Koc, E., Aydin, G., Akdeniz Ar, A., \& Boz, H. (2017). Emotions and Emotional Abilities in Service Failures and Recovery. Erdoğan Koç (Eds.), In the Service failures and recovery in tourism and hospitality: A practical manual (pp: 42-55). Oxfordshire, UK: CABI.

Koc, E., Ulukoy, M., Kilic, R., Yumusak, S., \& Bahar, R. (2017). The influence of customer participation on service failure perceptions. Total Quality Management \& Business Excellence, 28(3-4), 390404.

Kuo, Y. F., \& Wu, C. M. (2012). Satisfaction and postpurchase intentions with service recovery of online shopping websites: Perspectives on perceived justice and emotions. International Journal of Information Management, 32(2), 127138.

Kwon, S., \& Jang, S. S. (2012). Effects of compensation for service recovery: From the equity theory perspective. International journal of hospitality management, 31(4), 1235-1243.

Kwortnik, R. J. Jr., \& Han, X. (2011). The influence of guest perceptions of service fairness on lodging loyalty in China. Cornell Hospitality Quarterly, 52(3), 321-332.

López-López, I., Ruiz-de-Maya, S., \& Warlop, L. (2014). When sharing consumption emotions with strangers is more satisfying than sharing them with friends. Journal of Service Research, 17(4), 475-488.

Maher, A., \& Sobh, R. (2014). The role of collective angst during and after a service failure. Journal of Services Marketing, 28(3), 223-232.

Mattila, A. S. (1999). An examination of factors affecting service recovery in a restaurant setting. Journal of Hospitality \& Tourism Research, 23(3), 284298.

Mattila, A. S., \& Enz, C. A. (2002). The role of emotions in service encounters. Journal of Service Research, 4(4), 268-277.

Mattila, A. S., \& Patterson, P. G. (2004). The impact of culture on consumers' perceptions of service recovery efforts. Journal of Retailing, 80(3), 196206.

Mattila, A. S., \& Ro, H. (2008). Discrete negative emotions and customer dissatisfaction responses in a casual restaurant setting. Journal of Hospitality \& Tourism Research, 32(1), 89-107.

Maxham III, J. G. (2001). Service recovery's influence on consumer satisfaction, positive word-of-mouth, and purchase intentions. Journal of Business Research, 54(1), 11-24.

Maxham III, J. G., \& Netemeyer, R. G. (2002). A longitudinal study of complaining customers' evaluations of multiple service failures and recovery efforts. Journal of Marketing, 66(4), 5771.

Maxham III, J. G., \& Netemeyer, R. G. (2003). Firms reap what they sow: the effects of shared values and perceived organizational justice on customers' evaluations of complaint handling. Journal of Marketing, 67(1), 46-62.

McAlister, D. T., \& Erffmeyer, R. C. (2003). A content analysis of outcomes and responsibilities for consumer complaints to third-party organizations. Journal of Business Research, $56(4), 341-351$ 
McColl-Kennedy, J. R., Daus, C. S., \& Sparks, B. A. (2003). The role of gender in reactions to service failure and recovery. Journal of Service Research, 6(1), 66-82.

McCollough, M. A., Berry, L. L., \& Yadav, M. S. (2000). An empirical investigation of customer satisfaction after service failure and recovery. Journal of Service Research, 3(2), 121-137.

McDougall, G., \& Levesque, T. (1998). The effectiveness of recovery strategies after service failure: An experiment in the hospitality industry. Journal of Hospitality \& Leisure Marketing, 5(2-3), 27-49.

McQuilken, L., \& Robertson, N. (2011). The influence of guarantees, active requests to voice and failure severity on customer complaint behavior. International Journal of Hospitality Management, 30(4), 953-962.

Naghizadeh, R. (2019). Investigation on the relationship of service quality on tourist satisfaction and loyalty: Case study of Ardabil County. Journal of Multidisciplinary Academic Tourism, 4(1), 1-14.

Nikbin, D., Hyun, S. S., Baharun, R., \& Tabavar, A. A. (2015). The Determinants of Customers Behavioral Intentions after Service Failure: The Role of Emotions. Asia Pacific Journal of Tourism Research, 20(9), 971-989.

Odabaşı, Y., \& Barış, G. (2015). Tüketici Davranışı, İstanbul: MediaCat Akademi.

Oh, H. (1999). Service quality, customer satisfaction, and customer value: A holistic perspective. International Journal of Hospitality Management, 18(1), 67-82.

Ok, C., Back, K. J., \& Shanklin, C. W. (2007). Mixed findings on the service recovery paradox. The Service Industries Journal, 27(6), 671-686.

Oliver, R. L. (1980). A cognitive model of the antecedents and consequences of satisfaction decisions. Journal of Marketing Research, 460-469.

Oliver, R. L. (1981). Measurement and evaluation of satisfaction processes in retail settings. Journal of Retailing, 27(3), 25-48.

Oliver, R. L., Rust, R. T., \& Varki, S. (1997). Customer delight: foundations, findings, and managerial insight. Journal of Retailing, 73(3), 311-336.

Patterson, P. G., Cowley, E., \& Prasongsukarn, K. (2006). Service failure recovery: the moderating impact of individual-level cultural value orientation on perceptions of justice. International Journal of Research in Marketing, 23(3), 263-277.

Pedraja Iglesias, M., \& Jesus Yagüe Guillén, M. (2004). Perceived quality and price: their impact on the satisfaction of restaurant customers.
International Journal of Contemporary Hospitality Management, 16(6), 373-379.

Pugh, S. D. (2001). Service with a smile: Emotional contagion in the service encounter. Academy of Management Journal, 44(5), 1018-1027.

Richins, M. L. (1982). An investigation of consumers' attitudes toward complaining. Advances in Consumer Research, 9, 502-506.

Ryu, K., \& Han, H. (2010). Influence of the quality of food, service, and physical environment on customer satisfaction and behavioral intention in quick-casual restaurants: Moderating role of perceived price. Journal of Hospitality \& Tourism Research, 34(3), 310-329.

Schänzel, H. A. (2010). Whole-family research: Towards a methodology in tourism for encompassing generation, gender, and group dynamic perspectives. Tourism Analysis, 15(5), 555-569.

Schoenewolf, G. (1990). Emotional contagion: Behavioral induction in individuals and groups. Modern Psychoanalysis, 15, 49-61.

Sekaran, U. (1992). Research methods for business: A skill-building approach. 2nd. Edition. New York: John Wiley \& Sons.

Sekeran, U., \& Bougie, R. (2013). Research methods for business. A skill-building approach. West Sussex: John Wiley.

Şencan, H. (2005). Sosyal ve davranışsal ölçümlerde güvenilirlik ve geçerlilik. Ankara: Seçkin Yayıncılık.

Shamdasani, P. N., \& Balakrishnan, A. A. (2000). Determinants of relationship quality and loyalty in personalized services. Asia Pacific Journal of Management, 17(3), 399-422.

Şimşek, Ö. F. (2007). Yapısal eşitlik modellemesine giriş, temel ilkeler ve lisrel uygulamaları. Ankara: Ekinoks.

Smith, A. K., \& Bolton, R. N. (2002). The effect of customers' emotional responses to service failures on their recovery effort evaluations and satisfaction judgments. Journal of the Academy of Marketing Science, 30(1), 5-23.

Smith, A. K., Bolton, R. N., \& Wagner, J. (1999). A model of customer satisfaction with service encounters involving failure and recovery. Journal of Marketing Research, 36(3), 356-372.

Söderlund, M., \& Rosengren, S. (2010). The happy versus unhappy service worker in the service encounter: assessing the impact on customer satisfaction. Journal of Retailing and Consumer Services, 17(2), 161-169.

Song, J., \& Qu, H. (2017). The mediating role of consumption emotions. International Journal of Hospitality Management, 66, 66-76. 
Sparks, B., \& Fredline, L. (2007). Providing an explanation for service failure: context, content, and customer responses. Journal of Hospitality \& Tourism Research, 31(2), 241-260.

Spoor, J. R., \& Kelly, J. R. (2004). The evolutionary significance of affect in groups: Communication and group bonding. Group processes \& intergroup relations, $7(4)$, 398-412.

Tam, J. L. (2004). Customer satisfaction, service quality and perceived value: an integrative model. Journal of Marketing Management, 20(7-8), 897917.

Vijayalakshmi, V., \& Bhattacharyya, S. (2012). Emotional contagion and its relevance to individual behavior and organizational processes: A position paper. Journal of Business and Psychology, 27(3), 363-374.

Weber, K., Hsu, C. H., \& Sparks, B. A. (2014). Consumer Responses to Service Failure: The Influence of Acculturation. Cornell Hospitality Quarterly, 55(3), 300-313.

Wei, W., Miao, L., Cai, L. A., \& Adler, H. (2012). The influence of self-construal and co-consumption others on consumer complaining behavior. International Journal of Hospitality Management, 31(3), 764-771.

Wieseke, J., Geigenmüller, A., \& Kraus, F. (2012). On the role of empathy in customer-employee interactions. Journal of Service Research, 15(3), 316-331.

Wild, B., Erb, M., \& Bartels, M. (2001). Are emotions contagious? Evoked emotions while viewing emotionally expressive faces: quality, quantity, time course and gender differences. Psychiatry Research, 102(2), 109-124.

Wirtz, J., \& Mattila, A. S. (2004). Consumer responses to compensation, speed of recovery and apology after a service failure. International Journal of Service Industry Management, 15(2), 150-166.

Yang, W., \& Mattila, A. S. (2012). The role of tie strength on consumer dissatisfaction responses. International Journal of Hospitality Management, 31(2), 399-404.

Yılmaz, V., \& Çelik, E. H. (2009). Lisrel ile Yapısal Essitlik Modellemesi 1, Temel Kavramlar, Uygulamalar, Programlama. Ankara: Pegem Akademi.

Yüksel, A., \& Yüksel, F. (2003). Measurement of tourist satisfaction with restaurant services: A segmentbased approach. Journal of Vacation Marketing, $9(1), 52-68$.

Zeithaml, V. A., Berry, L. L., \& Parasuraman, A. (1988). Communication and control processes in the delivery of service quality. The Journal of Marketing, 52(2), 35-48.
Zhou, Y., Tsang, A. S., Huang, M., \& Zhou, N. (2014). Group service recovery strategies effectiveness: The moderating effects of group size and relational distance. Journal of Business Research, 67(11), 2480-2485. 
Appendix A. Scenario Describing a Group Service Failure at a Restaurant

Tonight, you and five of your close friends are coming together for a dinner at a high-end à la carte restaurant with a table service to relax after a busy week. You make the reservation by calling Rumeli Restaurant and inform your friends. That said, please consider the following scenario...

When you enter the restaurant, the receptionist greets you, confirms your reservation and escorts you to your table. The receptionist brings the menu to your table and leaves by saying that a waiter will come to take your orders. After 15 minutes, your friend Beril, who realizes that no waiter has come over, calls out a waiter. The waiter welcomes you and asks "May I take your order?" and three of you order mixed grill and the other three order pizza. One of you asks for his/her mixed grill rare cooked. And you specifically ask the waiter, "to serve the main dishes at the same time." Meanwhile, the waiter does not look at you as he is busy noting the orders on the bill and just nodes his head and walks out. Your friend Sercan serves your water. Around 20 minutes pass, but no one checks on you and you again call out a waiter. The waiter replies "Let me check with the kitchen now" but you see that he checks on another table to give their bill. Ten minutes later, the waiter brings the pizzas that 3 people ordered and leaves by saying he will bring the mixed grills in a minute. You tell your friends to start their dinner and "Our orders will arrive soon, do not let yours go cold." After ten minutes, the waiter comes with the mixed grills and forgets which of you ordered the underdone grill. Gürkan, telling that he ordered it and complains to the waiter saying that "Wish we all ordered pizza, at least we would not wait for each other."

Source: Authors 